\title{
The urgency of sex education in Latin America and the Caribbean
}

\section{A szexuális nevelés fontossága Latin-Amerikában és a Karib- térségben}

\section{CHRISTOPHER COPPIANO}

Christopher Coppiano: MA student; University of Pécs, Faculty of Humanities and Social Sciences, Institute of Social Relations, Department of Community and Social Studies; christophercoppiano@gmail.com

Christopher Coppiano: MA-hallgató; Pécsi Tudományegyetem, Bölcsészet- és Társadalomtudományi Kar, Társadalmi Kapcsolatok Intézete, Közösségi és Szociális Tanulmányok Tanszék; christophercoppiano@gmail.com

All children and adolescents should have the right to sex education. Article 26 of the Universal Declaration of Human Rights (1948) establishes that "Everyone has the right to education. [...] Education shall be directed to the full development of the human personality and to the strengthening of respect for human rights and fundamental freedoms.". Thus, the freedom to express sexuality with health and awareness, the freedom to know one's body, and the possibility of developing the personality through a healthy and responsible sexuality should be one of the primary focuses of contemporary education. However, this is not the reality of Latin America and the Caribbean, which hold the second highest rate of adolescent pregnancy in the world, which is estimated at 66.5 births per 1000 girls and adolescents between 15 and 19 years (Pan American Health Organization, 2018). In this case, the United Nations International Children's Emergency Fund [UNICEF] (2014) establishes that the adolescent fertility rate in this region "has not decreased in the same proportion as that at the global level. In fact, [...] it is expected that they will be the highest in the world and will remain stable between 2020 and 2100". In parallel, the United Nations AIDS (2018) estimates that Latin America and the Caribbean have a population of 77,000 children and adolescents between 10 and 19 years of age with HIV. In this sense, children and adolescents, especially from Latin America and the Caribbean, become a population being in a situation of greater vulnerability that requires special attention on sexual education.

In Ecuador, the national survey on family relations and gender-based violence against women of the National Institute of Statistics and Censuses of Ecuador shows that $64.9 \%$ of women in Ecuador have suffered at some point in their life some type of violence (National Institute of Statistics and Censuses [INEC], 2019). At the same time, in the last 13 years, 169 girls and adolescents up to 17 years of age have died during pregnancy, childbirth, or within 42 days after delivery (INEC, 2019). On the other hand, the opportunity cost of education due to adolescent pregnancy and early motherhood represented an economic loss for Ecuador of 59.6 million dollars, only in the year 2017 (UNICEF, 2020). These alarming figures are directly related to the deprivation of sex education in public schools by the Ministry of Education of Ecuador, and the rejection of a health system focused on the prevention of pregnancies among 
girls and adolescents. In this case, in Ecuadorian schools, sexual education has not been disseminated or developed because of harmful stereotypes and the influence of social prejudices and moral pressures that have hindered its being taught in the classrooms.

Nonetheless, the answer to solve these social dysfunctions are not based simply on a restructuring of the education system in Ecuador, or any country in Latin America and the Caribbean region, but on a transversal process of social work that allows achieving a collective responsibility of all members of society in order to prioritize the rights and the well-being of children and adolescents through the empowerment and the opportunity to engage people to make a social change of this magnitude. Sexual education has a deep impact in the construction of identity, since it implies the need to recognize people's rights to pleasure, to establish boundaries and have them respected, and to own their bodies beyond the normative discourses of shame and secrecy. A society that is built upon the respect, honor and recognition of sexual integrity can become closer to enhancing social bonds and heal the collective perception on desire and its expression, as well as protecting children's access to information and tools that will enable them voice their needs and sustain a healthier process of growth.

\section{References}

National Institute of Statistics and Censuses. (2019). Encuesta nacional sobre relaciones familiares y violencia de genero contra las mujeres. https://www.ecuadorencifras.gob.ec/documentos/webinec/Estadisticas_Sociales/Violencia_de_genero_2019/Documento\%20metodologico\%20EN VIGMU.pdf

Pan American Health Organization. (2018). Latin America and the Caribbean have the second highest adolescent pregnancy rates in the world.

https://www3.paho.org/hq/index.php?option=com_content\&view=article\&id=14163:latinamerica-and-the-caribbean-have-the-second-highest-adolescent-pregnancy-rates-in-theworld\&Itemid=1926\&lang $=\mathrm{fr}$

United Nations International Children's Emergency Fund. (2014). Vivencias y relatos sobre el embarazo en adolescentes. Una aproximación a los factores culturales, sociales y emocionales a partir de un estudio en seis países de la región. https://www.unicef.org/lac/media/6351/file/PDF\%20Publicación\%20Vivencias\%20y\%20relat os\%20sobre\%20el\%20embarazo\%20en\%20adolescentes\%20.pdf\#page63

United Nations International Children's Emergency Fund. (2020). El embarazo adolescente impacta en la economía de las mujeres y tiene un alto costo socioeconómico para el Estado. https://www.unicef.org/ecuador/comunicados-prensa/el-embarazo-adolescente-impacta-en-laeconom\%C3\%ADa-de-las-mujeres-y-tiene-un-alto

United Nations. (1948). Universal declaration of human rights. https://www.un.org/en/aboutus/universal-declaration-of-human-rights

United Nations. (1990). Convention on the rights of the child. https://www.ohchr.org/EN/ProfessionalInterest/Pages/CRC.aspx

United Nations AIDS. (2018). Información estratégica sobre adolescentes y el VIH en América Latina y el Caribe. https://www.unicef.org/lac/media/4381/file/PDF\%20Informe\%20VIH.pdf 